Authors' accepted manuscript, 5 February 2018

Published in : Biological Conservation 220, 272-279.

\title{
Facilitating ecosystem assembly: plant-soil interactions as a restoration tool
}

A.U. van der Bij*1, M. J. Weijters*2, R. Bobbink2, J.A. Harris3, M. Pawlett3, K. Ritz4, P. Benetková5, J. Moradi5, J. Frouz5,6 and R. van Diggelen1\#

1. Ecosystem Management Research Group, University of Antwerp, Universiteitsplein 1, 2610Antwerp-Wilrijk, Belgium

2. B-WARE Research Centre, Radboud University, P.O. Box 6558, 6503 GB Nijmegen, The Netherlands

3. School of Energy, Environment and Agrifood, Cranfield University, Bedfordshire, MK43 OAL, UK

4. Faculty of Science, University of Nottingham, Sutton Bonington Campus, Sutton Bonington, Leicestershire, LE12 SRD, UK

5. Institute for Environmental studies, Charles University, Benátská 2, 12800, Prague, Czech Republic

6. Institute of Soil Biology, Biological Centre Academy of Sciences of the Czech Republic, $\mathrm{Na}$ Sadkach 7, 37005 Ceske Budejovice, Czech Republic

* both authors contributed equally

\# corresponding author

\begin{abstract}
Although plant-soil interactions are increasingly recognized as an important factor in ecosystem restoration, their effects on community assembly during de novo ecosystem establishment are largely unknown. In a heathland restoration trial after topsoil removal we introduced either only aboveground heathland species with fresh herbage or both above- and belowground heathland species with sods to facilitate community assembly. Sod inoculation increased resemblance of the microbial community to the reference system, with a higher fungal and lower bacterial proportion to the community structure. Also densities of bacteriophagous and phytophagous nematodes, Acari and Collembola increased after sod inoculation. The cover of heathland plant species increased by $49 \%$ after sod inoculation. The introduction of solely aboveground heathland species increased the cover of these species by only $13 \%$, and did not affect soil community assembly. Additionally, the increase in cover of heathland species over time was inversely correlated to the cover of mesotrophic grassland species. Inverse correlations were also observed between changes in fungal and bacterial abundances. Simultaneous introduction of key species of both above- and below-ground communities had a critical effect on the establishment of both communities, providing a potential shortcut for successful restoration of target ecosystems on disturbed soils.
\end{abstract}

Key words:; restoration; ecological filters; fungi; heathlands; mesofauna; bacteria

\section{Introduction}

Ecosystem assembly is a fundamental concept in ecology. Traditionally the focus has been on the assembly of aboveground communities (Götzenberger et al. 2011), but in recent years the importance of belowground community composition has become increasingly recognised (Reynolds et al. 2003, Wardle et al. 2004). Two major pathways are identified in plant-soil interactions: a first, 
direct, pathway is associated with the interaction between roots and soil organisms such as symbionts and pathogens. A second, indirect, pathway includes interactions between decomposers and plants and concerns nutrient cycling rates and soil formation (Wardle et al. 2004). The extent to which aboveground community composition affects belowground development and vice versa is still largely unclear. It is suggested that the soil community may either follow or facilitate vegetation development, dependant on the ecosystem (Harris 2009).

Little is known about the sequence in which characteristic above- and below-ground species have to establish for a smooth ecosystem development. While especially late-successional plants may need particular soil organisms to function properly (De Deyn et al. 2003, Frouz et al. 2008), the establishment of these soil organisms themselves may depend on the presence of characteristic plant species which promote the development of a typical organic soil layer (Frouz et al. 2009). Studies that included analysis of both above- and below-ground development during succession of semi-natural grassland or dwarf shrub vegetation reported varying results: in some studies both above- and below-ground communities develop along similar lines (Lozano et al. 2014), while others report that belowground development either lags behind aboveground changes (e.g. Frouz et al. 2009, Holtkamp et al. 2008, Jangid et al. 2011) or precedes them (Van der Bij et al. 2016).

Filters are assumed to play an important role in vegetation assembly, especially abiotic conditions, dispersal and establishment are considered critical factors (Van Diggelen \& Marrs 2003, Cramer et al. 2008). A better understanding of how plant-soil interactions affect the establishment of characteristic plant species would add significantly to this knowledge and has not only theoretical value, but would also provide valuable insights for practical restoration, e.g. after topsoil removal. There a bare substrate is created with suitable abiotic conditions and an opportunity for new species to establish. Previous studies have shown that vegetation assembly can be facilitated by introducing seeds of target species (Holtkamp et al. 2008, Kiehl et al. 2010, Klimkowska et al. 2010) and it sounds reasonable that similar filters also apply for belowground community assembly. For example, dispersal limitation is assumed to be strong for soil fauna as Acari (Lehmitz et al. 2012), one of the most abundant soil fauna groups in oligotrophic systems (Wardle et al. 2004, Frouz et al. 2009). Facilitation of soil community assembly would be a logical next step to further enhance ecosystem restoration (Kardol \& Wardle 2010). However, studies that explored this option by inoculation experiments showed varying results (Pywell et al. 2007, Kardol et al. 2009, Wubs et al. 2016).

Although the extent to which plant-soil interactions affect ecosystem assembly remains largely unknown, several papers emphasized their importance for restoration ecology (Harris 2009, Kardol \& Wardle 2010, Van der Putten et al. 2013). In the present study we assessed the potential of plant-soil interactions in de novo heathland ecosystem establishment. In a field trial immediately after topsoil removal we introduced either only aboveground species by means of fresh herbage, or simultaneously both above- and below-ground species by means of sods. We monitored the parallel development of vegetation and soil community to assess the following research question: does the simultaneous introduction of above- and below-ground species in early succession have a synergistic effect on heathland community assembly? We hypothesized that introduction of the soil community in early succession would enhance vegetation assembly.

\section{Materials and methods}

\subsection{Site description}

The Dwingelderveld National Park ( $52^{\circ} 48^{\prime} 14.3$, E 6 ${ }^{\circ} 24^{\prime} 38.6$ ) is a large lowland heathland (altitude $7 \mathrm{~m}$ ) in the Netherlands. It has a maritime temperate climate ( $\mathrm{Cfb}$ ) with an average annual temperature of $8.8^{\circ} \mathrm{C}$ and an annual average rainfall of $783 \mathrm{~mm}$ (http://en.climatedata.org/location/105881/). In the 1930's 200 ha in the centre of the area was converted from 
heathland into agricultural grasslands and restored again in 2011-2012 with topsoil removal (30-40 $\mathrm{cm}$ ), only road sides with mesotrophic grassland were left untouched. Compared to reference values from the meta-analysis of De Graaf et al. (2009) and measurements in reference sites nearby (Table 1) $\mathrm{pH}$ and soil buffering were higher than in typical Dutch heathlands but after topsoil removal nutrient levels lay well within the range of typical heathlands

\subsection{Experimental setup}

The experiment was installed in November 2011 immediately after topsoil removal. We manipulated both the abiotic and the biotic environment in a full-factorial set up. The soil-pH was manipulated by (1) addition of acid ( $150 \mathrm{~g}$ elemental S per $\mathrm{m}^{2}$ ), (2) addition of lime (200 g Dolokal per $\mathrm{m}^{2}$ ) or (3) left untouched. We manipulated the biotic conditions by establishing three inoculation treatments: (1) introduction of aboveground parts of heathland plant species, (2) addition of both plant species and soil community or (3) control. We did not measure the effects of adding only the soil community, because we were not capable to remove seeds from the added soil without severely disturbing the soil community. Each combination of treatments consisted of 3 replicates. The experiment was set up in 27 random plots of $15 \mathrm{~m} \times 15 \mathrm{~m}$ with $2 \mathrm{~m}$ buffers. In November 2011 we added elemental Sulfur or Dolokal and in December 2011 we spread crumbled sods from nearby well-developed dry heathlands. These sods contained the existing vegetation, the soil seed bank and the soil community. Sods were collected by cutting the upper $5 \mathrm{~cm}$ of a nearby dry heathland and were added immediately to the experimental plots in a ratio of 1:15 (i.e. donor material of $1 \mathrm{~m}^{2}$ on $15 \mathrm{~m}^{2}$ experimental plot). Aboveground plant material was added via the introduction of fresh herbage collected after seed setting of the dominant plant species Calluna vulgaris (L.) Hull in September 2012, the first opportunity after installing the experiment. This material was collected from a nearby well-developed dry heathland and added at the plots immediately after the mowing in a ratio of 1:2. Control plots remained unaltered after topsoil removal.

The number of germinable $C$. vulgaris seeds added per $\mathrm{m}^{2}$ was expected to differ between both inoculation treatments due to the different ratios in which the donor materials were added. We assessed these figures by using data from Legg et al. (1992) on the number of viable seeds in the seed bank and the annual seed production per $\mathrm{m}^{2}$ for mature dry heathlands in combination with a germination percentage of $75 \%$ of fresh heather seeds (Spindelbock et al. 2013). We calculated that we added an average of 34125 germinable seeds per $\mathrm{m}^{2}$ with fresh herbage and 15800 per $\mathrm{m}^{2}$ with sods. Since we introduced a high number of seeds in both treatments, we expected that seed availability was not a limiting factor for the establishment of $C$. vulgaris.

\subsection{Microbial community}

In 2009, before topsoil removal, we took three soil samples in the agricultural grassland from a layer just below the planned removal depth as starting point for microbial community development. Soil samples from the experimental plots ( $5 \mathrm{~cm}$ depth) were taken immediately after topsoil removal before the treatments were imposed and after 2 years in November 2013. Nearby dry heathlands which were used as source for the sod-treatment were sampled as a reference soil $(n=3)$ at the same time. In each sampling point a composite sample of $3 \times 100 \mathrm{~cm}^{3}$ soil was obtained with Kopecky rings. Aliquots of the soil were refrigerated for the analysis of microbial biomass or freeze-dried for phospholipid fatty acid (PLFA) analysis.

Microbial biomass-C was determined with the fumigation-extraction procedure (Jenkinson \& Powlson 1976) using $\mathrm{K}_{\mathrm{ec}}$ of 0,45 (Vance \& Jenkinson 1987). Microbial community phenotypic structure was measured with PLFA analysis using a modified method from Frostegård et al. (1993) according to the methods described by Courtney et al. (2014). 


\subsection{Soil fauna}

Soil fauna was sampled together with the microbial samples. Samples were stored at $10^{\circ} \mathrm{C}$ for nematode community analysis. Nematodes were extracted from $10 \mathrm{~g}$ soil with a modified Bergmann funnel (Hánĕl 1995) for 48 hours, after which they were fixed with formaldehyde and transferred to microscopic slides. Nematodes were divided into feeding groups according to Yeates et al. (1993). Soil mesofauna groups (Acari and Collembola) were extracted with a Tullgren apparatus and sorted under a dissection microscope as described by Frouz (1997).

\subsection{Vegetation}

Two permanent quadrats $(2 \mathrm{~m} \times 2 \mathrm{~m})$ were established at the centre of each plot. In July-August of each year we made vegetation relevés according to the Londo scale (Londo 1976). In the donor sites for herbage and sods 4 vegetation relevés $(2 \mathrm{~m} \times 2 \mathrm{~m})$ were made in August 2012. Plant species were classified into 3 categories: characteristic heathland species, typical mesotrophic grassland species species and other species. Species with a faithfulness of at least $10 \%$ to the dry heathland association (SynBioSys, Hennekens et al. 2010) were labelled characteristic heathland species.

\subsection{Data handling and statistics}

Before analysis normality of the residuals and equality of variances were checked, nematode and mesofauna data needed a $\ln (x+1)$ transformation to meet the criteria. We checked the effects of the treatments on soil chemical characteristics with a linear mixed model. Addition of Sulfur or Dolokal had a significant effect on soil pH and soil base status but did not affect plant nutritional parameters (Table 1 in Appendix). Since the biotic treatments had no significant effects on any of the measured soil chemical parameters we pooled the abiotic treatments and analysed the effects of the biotic treatments only. Treatment effects and values of the reference heathlands were tested with an Analysis of Variance (ANOVA), a post-hoc Tukey test was used to determine individual differences. Only for microbial community composition pre-treatment measurements of the original agricultural grasslands deep horizon were included as starting point. Since both vegetation and soil fauna of the agricultural grassland were removed with topsoil removal, they did not represent the actual starting points and were therefore not included in further analysis.

PLFA data were subjected to a Principal Component Analysis (PCA). We tested treatment effects with a Multivariate Analysis of Variance (MANOVA) with PCA1 and PCA2 as dependent variables and treatments (including starting points and reference heathlands) as fixed factor. On both PCA1 and PCA2 treatment effects were determined separately with an ANOVA and a post-hoc Tukey test. We determined correlations in the rate of change per year $(\triangle)$ between different species categories within plant, microbial- and mesofauna communities and between those communities with a twosided Pearson correlation test. For statistics we used R (R Core Team 2016) and the nlme-package for LME (Pinheiro et al. 2015).

\section{Results}

\subsection{Microbial community}

After topsoil removal microbial biomass was $70 \pm 13 \mu \mathrm{g} \mathrm{micC} \mathrm{g}^{-1}$ soil, compared to $770 \pm 220 \mu \mathrm{g} \mathrm{micC} \mathrm{g}^{-1}$ soil in the reference heathland (ANOVA, F: 6.26, p<0.0001, Table 2). In the first two years of the experiment microbial biomass increased only after sod inoculation, while there were no differences over time in the other treatments (ANOVA, F: 3.10, p: 0.017, Tukey test, $p<0.05$ ). Relative bacterial contribution to the microbial community structure in the control and after herbage addition remained similar to the deep horizon of the original grassland (Figure 1), while sod inoculation 
reduced the bacterial contribution (ANOVA, F: 6.54, p: 0.019). In contrast, relative fungal contribution increased significantly after sod inoculation compared to the other treatments (ANOVA, $\mathrm{F}: 31.37, \mathrm{p}<0.0001$ ), although it was still lower than in the reference heathland (Tukey test, $p<0.05$ ).

A PCA based on all PLFA's showed a clear distinction between sod inoculation and the other treatments (MANOVA, F: 8.37, p<0.0001). Microbial phenotypic composition changed in all plots after topsoil removal compared to the original agricultural deep horizon (Figure 2). Sod inoculation increased the resemblance of microbial phenotypic composition to the reference heathland within 2 years, after the addition of herbage it did not differ significantly from the control.

\subsection{Soil fauna}

After 2 years densities of all nematode feeding guilds except omnivores were significantly lower in the experimental plots compared to the reference heathlands (Table 3, Tukey test, $p<0.05$ ). Total nematode densities in the experimental plots reached maximal $7 \%$ of the values of the reference heathlands. Only bacteriophagous nematodes increased significantly after sod inoculation (ANOVA, $\mathrm{F}: 32.37, \mathrm{p}<0.0001)$. Although densities of other feeding guilds showed an increasing trend along the inoculum gradient, there were no significant differences.

Densities of both Acari (ANOVA, F: 13.50, p<0.0001) and Collembola (ANOVA, F: 4.02, p: 0.017) increased along the inoculum gradient (Figure 3 ), with higher densities after sod inoculation compared to the control and intermediate values after the addition of herbage (Tukey test, $p<0.05$ ). 2 years after sod inoculation Collombola densities did not differ significantly from reference heathlands, while densities of Acari were still much lower (Tukey test, $\mathrm{p}<0.05$ ).

\subsection{Vegetation}

The cover of characteristic heathland species increased along the inoculum gradient (ANOVA, F: $120.33, p<0.0001$ ), with a $13 \%$ increase after the addition of herbage and a further $36 \%$ increase after sod inoculation (Figure 4). 3 years after sod inoculation characteristic heathland species covered more than 50 percent of the surface. Typical mesotrophic grassland species showed the opposite pattern (ANOVA, F: 13.78, p<0.0001), with significantly lower cover after both inoculation treatments compared to the control. This contrast between heathland and mesotrophic grassland species resulted in a different balance along the inoculum gradient: grassland species dominated the control (ANOVA, F: 197.79, $p<0.0001$, Tukey test, $p<0.05$ ) while heathland species were dominant after sod inoculation (ANOVA, F: 120.20, p<0.0001, Tukey test, $p<0.05$ ). After the addition of herbage the cover of both categories was equal (ANOVA, $F=1.17, P=0.287$, Tukey test, $P>0.05$ ). Total herb cover reflected the increased cover of heathland species with significant higher values after sod inoculation (ANOVA, F: 29.06, p<0.0001).

\subsection{Within and between community linkage}

Although the magnitude smaller microbial biomass in the experiment compared to the reference heathlands indicates that the microbial community was still far from the reference state, all treatments showed a shift in the relative contribution of fungi and bacteria but the fastest changes occurred in the soil addition treatment (Figure 5). The maximal herb cover in the experimental plots after 3 years was between $60-70 \%$, suggesting minimal competition for light and space. Remarkably, also here an inverse correlation was found in the rate of change per year of the cover of heathland and mesotrophic grassland species (Pearson correlation: $-0.89, p<0.001$ ). Both mesofauna groups showed a positive correlation (Pearson correlation: $0.84, p<0.0001$ ), suggesting minimal competition. The rate of change per year between the cover of heathland species aboveground and the relative contribution of fungi belowground showed a strong positive correlation (Pearson correlation: 0.69, 
$\mathrm{p}<0.0001$ ), as did the relative contribution of fungi and total mesofauna densities (Pearson correlation: $0.63, \mathrm{p}: 0.0006)$.

\section{Discussion}

\subsection{Below-ground community assembly in relation to above-ground composition}

After 2 years both the above- and below-ground community in the control treatment showed no resemblance to the heathlands some 100 metres away but only to the mesotrophic grassland in the road sides of the immediate surroundings, which suggests strong dispersal limitation for heathland communities. In contrast, both inoculation treatments showed a clear development towards heathland. Introduction of seeds by fresh herbage promoted aboveground community assembly, as also reported in other studies (Holtkamp et al. 2008, Kiehl et al. 2010, Klimkowska et al. 2010), but did not affect the belowground community. In contrast, sod inoculation did lead to increased microbial biomass, fungal/bacteria ratio and soil fauna density and accelerated vegetation assembly even further. These differences suggest that the belowground community does not automatically follow the aboveground community and that only the simultaneous presence of both above- and below-ground heathland species leads to a fast assembly towards the target ecosystem. Our results show that plant-soil interactions can play a critical role in de novo ecosystem establishment. In the short term, simultaneous introduction of target above- and belowground species has a synergistic effect on both above- and below-ground community assembly.

The presence of above- and below-ground heathland species alone does not necessarily lead to restored plant-soil interactions (Kardol \& Wardle 2010). After 2 to 3 years vegetation cover and microbial biomass were still far from the reference state, leading to conditions where competition for light or space are likely still minimal. Nevertheless, an inverse correlation between the cover of heathland and grassland species aboveground and fungi and bacteria belowground was present in this stage, especially after sod inoculation. These results suggest that addition of above- and belowground heathland species not only reinforces their own establishment, but also reduces the establishment of non-target species. In such situation, where competition between plants is probably still very low, plant-soil interactions may be the main mechanism determining the balance between grassland and heathland species (e.g. Kardol et al. 2006, Bonkowski \& Roy 2012). This may lead to priority effects that determine vegetation composition for decades (Cramer et al. 2008).

\subsection{Assembly pathways}

Three different assembly pathways developed in the different treatments, with the most distinct differences between the control treatment and after sod inoculation. In the control treatment both above- and below-ground communities showed high resemblance to mesotrophic grasslands. The lack of sufficient seeds of heathland species combined with a high seed pressure of grassland species from the immediate surroundings (Klimkowska et al. 2010) seems to direct vegetation development towards a grassland. When the herb layer closes and recruitment gaps are no longer present, heathland species are likely to have large difficulties to establish and might remain absent from the community for a long time (Cramer et al. 2008).

A second pathway was followed after sod inoculation, where both above- and below-ground communities showed a higher resemblance to reference heathlands. Further assembly may depend on the infection rate of heather (C. vulgaris) by ericoid mycorrhiza. We did not measure mycorrhiza separately but the lower overall fungal content as compared to reference heathlands does suggest a low(er) infection rate in such former agricultural soils (Diaz et al. 2006, 2008). This interaction between $C$. vulgaris and ericoid mycorrhiza may favour both sides by production of recalcitrant litter by $C$. vulgaris and selective removal of labile nutrients by mycorrhiza (Read et al. 2004). When this 
symbiotic relation establishes sufficiently, heathland species are likely to remain dominant in the mid- to long term. This process might contribute to the inverse correlation between the cover of grassland and heathland species, suggesting that sod inoculation not only facilitates community assembly but also ecosystem functioning (Bever et al. 2010).

The third pathway, manifest after the addition of herbage, showed a mismatch between above- and below-ground communities: aboveground heathland and grassland species had similar cover while the community belowground was almost identical to that of an agricultural grassland. While after both inoculation treatments the estimated number of $C$. vulgaris plants per area was similar, their growth and thereby cover was lower after the addition of herbage, possibly reflecting a lower mycorrhizal infection rate (Diaz et al. 2006). Mycorrhizal infection rate in the first decade could be the tipping point for this pathway. A high rate might lead to heathland species gaining dominance and ecosystem development converging with the pathway after sod inoculation. Alternatively, the combination of an agriculturally-configured soil community and high cover of grassland species may tip the balance in favour of a grassland system by a self-reinforcing feedback loop of higher decomposition rates, higher productivity, higher litter quality and faster nutrient cycling (Bever et al. 2010, Kardol \& Wardle 2010).

The simultaneous introduction of key species from both above- and below-ground with sod inoculation enhanced and accelerated ecosystem assembly towards the target system, and demonstrates the potential of plant-soil interactions in early succession (Harris 2009). Without introduction of key species, both above- and below-ground communities remained stuck in an agricultural setting despite favourable abiotic conditions for heathland development. The trajectory after the addition of herbagemight either converge with the pathway after sod inoculation when specific plant-soil interactions establish or switch towards a grassland in their absence.

\subsection{Implications for ecosystem restoration}

Our results show that the simultaneous introduction of key above- and below-ground species enhances and accelerates the restoration of oligotrophic systems after soil disturbance. We found that addition of the belowground community has a significant effect on vegetation composition (Wubs et al., 2016). Such method provides a potential shortcut for quickly re-establishing target oligotrophic ecosystems after topsoil removal, on post-mining sites or other newly created surfaces. To maximize restoration success, sufficient material from both above- and below-ground communities, ideally in the form of sods, is to be added immediately after soil disturbance.

\section{Acknowledgements}

This study was funded by LIFE+ (LIFE08 NAT/NL/000192), the province of Drenthe and the Knowledge Network for Restoration and Management of Nature (OBN) in The Netherlands. We thank the local site managers from Staatsbosbeheer and Natuurmonumenten for their help and support and Jaap van Roon for his trust and guidance.

\section{References}

Bever, J.D., Dickie, I.A., Facelli, E., Facelli, J.M., Klironomos, J., Moora, M., Rillig, M.C., Stock, W.D., Tibbett, M. \& Zobel, M. 2010. Rooting theories of plant community ecology in microbial interactions. Trends Ecol. Evol. 25, 468-478

Bonkowski, M. \& Roy, J. 2012. Decomposer community complexity affects plant competition in a model early successional grassland community. Soil Biol. Biochem. 46, 41-48 
Courtney, R., Harris, J.A. \& Pawlett, M. 2014. Microbial community composition in a rehabilitated bauxite residue disposal area: a case study for improving microbial community composition. Restor. Ecol. 22, 798-805

Cramer, V.A., Hobbs, R.J. \& Standish, R.J. 2008. What's new about old fields? Land abandonment and ecosystem assembly. Trends Ecol. Evol. 23, 104-112

De Deyn, G.B., Raaijmakers, C.E., Zoomer, H.R., Berg, M.P., De Ruiter, P.C., Verhoef, H.A., Bezemer, T.M. \& Van der Putten, W.H. 2003. Soil invertebrate fauna enhances grassland succession and diversity. Nature $422,711-713$

De Graaf, M.C.C., Bobbink, R., Smits, N.A.C., Van Diggelen, R. \& Roelofs, J.G.M. 2009. Biodiversity, vegetation gradients and key biogeochemical processes in the heathland landscape. Biol. Cons. 142, 2191-2201

Diaz, A., Green, I., Benvenuto, M. \& Tibbett, M. 2006. Are ericoid mycorrhizas a factor in the success of Calluna vulgaris heathland restoration? Restor. Ecol. 14, 187-195

Diaz, A., Green, I. \& Tibbett, M. 2008. Re-creation of heathland on improved pasture using top soil removal and sulphur amendments: edaphic drivers and impacts on ericoid mycorrhizas. Biol. Cons. $141,1628-1635$

Frostegård, Å., Tunlind, A. \& Bååth, E. 1993. Phospholipid fatty acid composition, Biomass, and activity of microbial communities from two soil types experimentally exposed to different heavy metals. Appl. Environ. Microbiol. 59, 3605-3617

Frouz, J. 1997. Changes in communities of soil dwelling dipteran larvae during secondary succession in abandoned fields. Eur. J. Soil Biol. 33, 57-65

Frouz, J., Prach, K., Pižl, V., Háněl, L., Starý, J., Tajovský, K., Materna, J., Balik, V., Kalčik, J. \& Řehounková, K. 2008. Interactions between soil development, vegetation and soil fauna during spontaneous succession in post mining sites. Eur. J. Soil Biol. 44, 109-121

Frouz, J., Van Diggelen, R., Pižl, V., Starý, J., Hánĕl, L., Tajovský, K. \& Kalčík, J. 2009. The effect of topsoil removal in restored heathland on soil fauna, topsoil microstructure, and cellulose decomposition: implications for ecosystem restoration. Biodivers. Conserv. 18, 3963-3978

Götzenberger, L., De Bello, F., Bråthen, K.A., Davison, J., Dubuis, A., Guisan, A., Leps, J., Lindborg, R., Moora, M., Pärtel, M., Pellissier, L., Pottier, J., Vittoz, P., Zobel, K. \& Zobel, M. 2011. Ecological assembly rules in plant communities - approaches, patterns and prospects. Biol. Rev. 87, 111-127

Hánĕl, L. 1995. Secondary successional stages of soil nematodes in cambisols of South Bohemia. Nematologica 41, 197-218

Harris, J. 2009. Soil microbial communities and restoration ecology: facilitators or followers? Science $325,573-574$

Heinze, J., Bergmann, J., Rilling, M.C., \& Joshi, J. 2015. Negative biotic soil-effects enhance biodiversity by restricting potentially dominant plant species in grasslands. Perspect. Plant Ecol. 17, 227-235 
Hennekens, S.M., Smits, N.A.C. \& Schaminée, J.H.J. 2010. SynBioSys Nederland versie 2. Alterra, Wageningen UR.

Holtkamp, R., Kardol, P., Van der Wal, A., Dekker, S.C., Van der Putten, W.H. \& De Ruiter P.C. 2008. Soil food web structure during ecosystem development after land abandonment. Appl. Soil Ecol. 39, 23-34

Jangid, K., Williams, M.A., Franzluebbers, A.J., Schmidth, T.M., Coleman, D.C. \& Whitman, W.B. 2011. Land-use history has a stronger impact on soil microbial community composition than aboveground vegetation and soil properties. Soil Biol. Biochem. 43, 2184-2193

Jenkinson D.S. \& Powlson D.S. 1976. The effects of biocidal treatments on metabolism in soil-I. fumigation with chloroform. Soil Biol. Biochem. 8, 167-177

Kardol, P., Bezemer, T.M. \& Van der Putten, W.H. 2006. Temporal variation in plant-soil feedback controls succession. Ecol. Lett. 9, 1080-1088

Kardol, P., Bezemer, T.M. \& Van der Putten, W.H. 2009. Soil organism and plant introductions in restoration of species-rich grassland communities. Restor. Ecol. 17, 258-269

Kardol, P. \& Wardle, D.A. 2010. How understanding aboveground-belowground linkages can assist restoration ecology. Trends Ecol. Evol. 25, 670-679

Kiehl, K., Kirmer, A., Donath, T.W., Rasran, L. \& Hölzel, N. 2010. Species introduction in restoration projects - Evaluation of different techniques for the establishment of semi-natural grasslands in Central and Northwestern Europe. Basic Appl. Ecol. 11, 285-299

Klimkowska, A., Kotowski, W., Van Diggelen, R., Grootjans, A.P., Dzierża, P. \& Brzezińska, K. 2010. Vegetation re-development after fen meadow restoration by topsoil removal and hay transfer. Restor. Ecol. 18, 924-933

Legg, C.J., Maltby, E. \& Proctor, M.C.F. 1992. The ecology of severe moorland fire on the North York Moors: seed distribution and seedling establishment of Calluna vulgaris. J. Ecol. 80, 737-752

Lehmitz, R., Russell, D., Hohberg, K., Christian, A. \& Xylander, W.E.R. 2012. Active dispersal of oribatid mites into young soils. Appl. Soil Ecol. 55, 10-19

Londo, G. 1976. The decimal scale for relevés of permanent quadrats. Vegetatio, 33, 61-64

Lozano, Y.M., Hortal, S., Arman, C. \& Pugnaire, F.I. 2014. Interactions among soil, plants, and microorganisms drive secondary succession in a dry environment. Soil Biol. Biochem. 78, 298-306

Pinheiro, J., Bates, D., DebRoy, S., Sarkar, D. \& R Core Team 2015. _nlme: Linear and Nonlinear Mixed Effects Models_. R package version 3.1-122, URL: http://CRAN.R-project.org/package=nlme

Pywell, R.F., Bullock, J.M., Tallowin, J.B., Walker, K., Warman, E.A. \& Masters, G. 2007. Enhancing diversity of species-poor grasslands: an experimental assessment of multiple constraints. J. Appl. Ecol. 44, 81-94

R Core Team, 2016. R: A Language and Environment for Statistical Computing. R Foundation for Statistical Computing, Vienna, Austria (2016) http://www.R-project.org 
Read, D.J., Leake, J.R. \& Perez-Morena, J. (2004) Mycorrhizal fungi as drivers of ecosystem processes in heathland and boreal forest biomes. Can. J. Bot. 82, 1243-1263

Reynolds, H.L., Packer, A., Bever, J.D. \& Clay, K. 2003. Grassroots ecology: plant-microbe-soil interactions as drivers of plant community structure and dynamics. Ecology, 84, 2281-22 Schmidt, S.K., Nemergut, D.R., Darcy, J.L. \& Lynch, R. (2014) Do bacterial and fungal communities assemble differently during primary succession? Mol. Ecol. 23, 254-258

Spindelböck, J.P., Cook, Z., Daws, M.I., Heegaard, E., Maren, I.E. \& Vandvik, V. 2013. Conditional cold avoidance drives between-population variation in germination behaviour in Calluna vulgaris. Ann. Bot-London 112, 1-10

Van der Bij, A.U., Pawlett, M., Harris, J.A., Ritz, K. \& Van Diggelen, R. 2016. Soil microbial community assembly precedes vegetation development after drastic techniques to mitigate effects of nitrogen deposition. Biol. Cons. 212, 476-483

Van der Putten, W.H., Bardgett, R.D., Bever, J.D., Bezemer, T.M., Casper, B.B., Fukami, T., Kardol, P., Klironomos, J.N., Kulmatiski, A., Schweitzer, J.A., Suding, K.N., Van de Voorde, T.F.J. \& Wardle, D.A. 2013. Plant-soil feedbacks: the past, the present and future challenges. J. Ecol. 101, 265-276

Van Diggelen, R. \& Marrs, R.H. 2003. Restoring plant communities - introduction. Appl. Veg. Sci. 6, $106-110$

Vance, E.D. \& Jenkinson D.S. 1987. An extraction method for measuring soil microbial biomass C. Soil Biol. Biochem. 19, 703-707

Wardle, D.A., Bardgett, R.D., Klironomos, J.N., Setälä, H., Van der Putten, W.H. \& Wall, D.H. 2004. Ecological linkages between aboveground and belowground biota. Science, 304, 1629-1633

Wubs, E.R., van der Putten, W.H., Bosch, M. and Bezemer, T.M. 2016. Soil inoculation steers restoration of terrestrial ecosystems. Nature Plants 2, 1-5

Yeates, C.W., Bongers, T., de Goede, R.G.M., Freckman, D.W. \& Georgieva, S.S. 1993. Feeding habits in soil nematode families and genera - an outline for soil ecologists. Journal of Nematology 25, 315331. 


\begin{tabular}{llllll}
\hline Site & $\begin{array}{l}\text { Soil pH- } \\
\mathrm{H}_{2} \mathrm{O}\end{array}$ & $\begin{array}{l}\text { Exchangeable base } \\
\text { cations } \\
\mu \mathrm{eq} / \mathrm{kg} \text { soil }\end{array}$ & $\begin{array}{l}\text { Plant available } \\
\text { phosphorus } \\
\mu \mathrm{mol} / \mathrm{kg} \text { soil }\end{array}$ & $\begin{array}{l}\mathrm{N} \mathrm{mineral}\left(\mathrm{NO}_{3}+\right. \\
\left.\mathrm{NH}_{4}\right) \\
\mu \mathrm{mol} / \mathrm{kg} \text { soil }\end{array}$ & $\begin{array}{l}\text { Organic } \\
\text { matter } \\
\% \text { dry soil }\end{array}$ \\
\hline Experiment & $5.61(0.03)$ & $10304 \pm 894$ & $296.0 \pm 48.6$ & $40.4 \pm 16.6$ & $2.1 \pm 0.2$ \\
\hline $\begin{array}{l}\text { Dry heath } \\
\text { reference }\end{array}$ & $3.8-4.9$ & $485-7690$ & $100-700$ & $1-220$ & $1.6-11.9$ \\
\hline
\end{tabular}

506

A

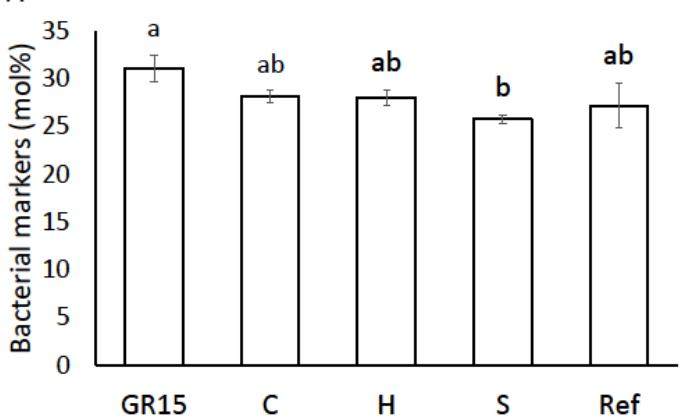

Table 2. Results of ANOVA-models of the inoculum gradient including reference heathlands and only for microbial community the deep original grassland horizon. Statistics of solely the experimental treatments are included in Table 2 of the Appendix.

Component ANOVA model df $F \quad p$

Microbial community

$\begin{array}{llll}\text { Fungal marker } & 4 & 31.37 & <0.0001\end{array}$

$\begin{array}{llll}\text { Bacterial markers } & 4 & 6.54 & 0.019\end{array}$

Nematodes

$\begin{array}{llll}\text { Bacteriophagous } & 3 & 32.37 & <0.0001\end{array}$

$\begin{array}{llll}\text { Phytophagous } & 3 & 7.96 & 0.0006\end{array}$

$\begin{array}{llll}\text { Mycophagous } & 3 & 10.63<0.0001\end{array}$

$\begin{array}{llll}\text { Omnivores } & 3 & 2.15 & 0.119\end{array}$

$\begin{array}{llll}\text { Total } & 3 & 15.67 & <0.0001\end{array}$

Mesofauna

$\begin{array}{llll}\text { Acari } & 3 & 13.50 & <0.0001\end{array}$

$\begin{array}{llll}\text { Collembola } & 3 & 4.02 & 0.017\end{array}$

Vegetation

$\begin{array}{llll}\text { Cover heathland species } & 3 & 120.33 & <0.0001\end{array}$

$\begin{array}{llll}\text { Cover grassland species } & 3 & 13.78 & <0.0001\end{array}$

\begin{tabular}{llll} 
Total cover & 3 & 29.06 & $<0.0001$ \\
\hline
\end{tabular}




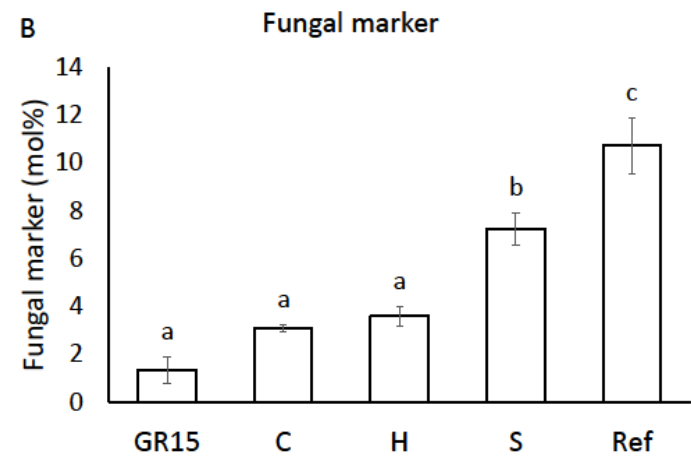

Figure 1. The sum of the relative contribution of the bacterial PLFA's (A) and the fungal PLFA (B).

Means \pm S.E., letters indicate Tukey outcomes. GR15: deep horizon grassland; C: control; H: herbage; S: sods and Ref: reference heathland.

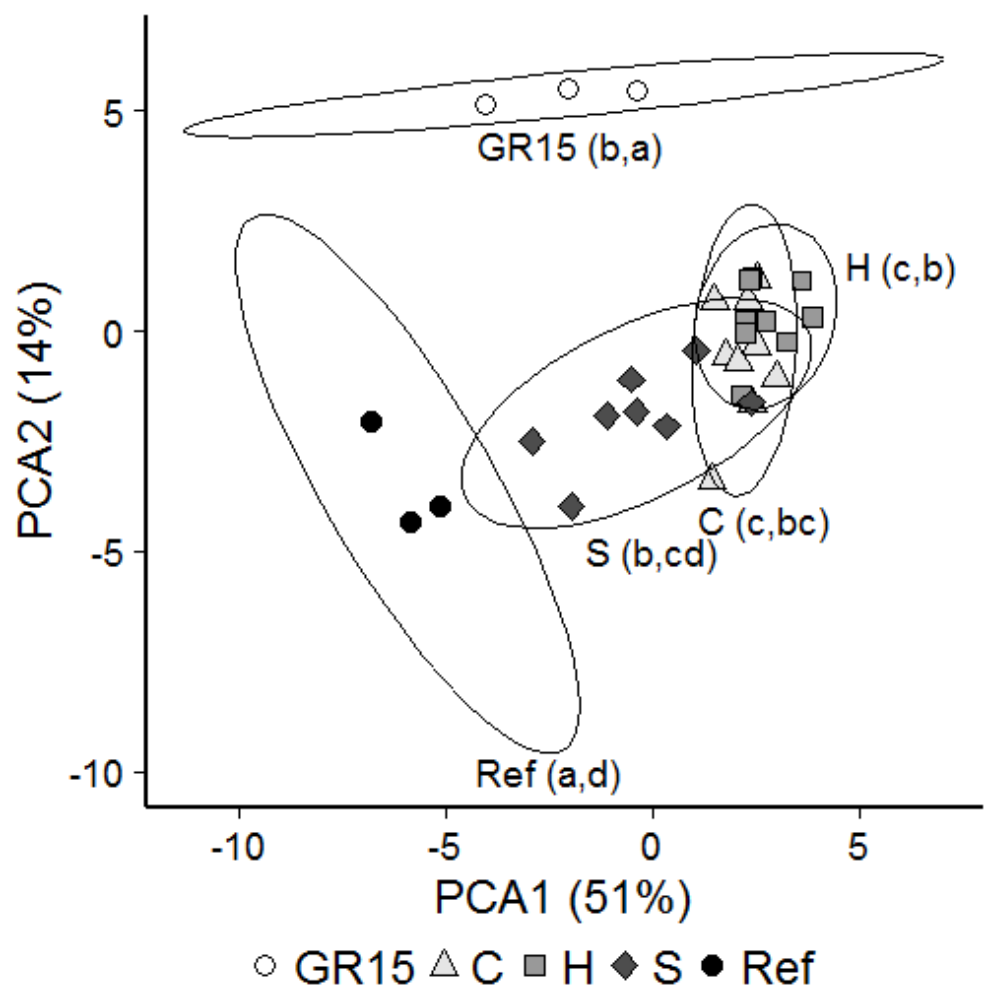

Figure 2. A PCA based on all measured PLFA's. GR15: deep horizon original grassland; C: control; H: addition of herbage; S: sod inoculation and Ref: reference heathland. Ellipses represent $95 \%$ confidence intervals. Letters indicate Tukey outcomes from PCA 1 and PCA2.

Table 3. Nematode densities for feeding guilds per $10 \mathrm{~g}$ dry soil. Means \pm S.E., letters indicate Tukey outcomes.

\begin{tabular}{lllll}
\hline Feeding guild & Control & Herbage & Sods & Reference \\
\hline Bacteriophagous & $1.67 \pm 0.24(\mathrm{a})$ & $3.00 \pm 0.99(\mathrm{ab})$ & $5.67 \pm 1.21(\mathrm{~b})$ & $168 \pm 104(\mathrm{c})$ \\
Phytophagous & $0.00 \pm 0.00(\mathrm{a})$ & $0.11 \pm 0.11(\mathrm{a})$ & $0.67 \pm 0.29(\mathrm{a})$ & $4.67 \pm 2.40$ (b) \\
Mycophagous & $0.11 \pm 0.11$ (a) & $1.33 \pm 0.90(\mathrm{a})$ & $3.22 \pm 1.58(\mathrm{a})$ & $25.67 \pm 12.91(\mathrm{~b})$ \\
Omnivores & $2.44 \pm 0.80$ (a) & $3.67 \pm 0.96(\mathrm{a})$ & $4.67 \pm 1.91(\mathrm{a})$ & $10.00 \pm 3.46(\mathrm{a})$ \\
Total & $4.22 \pm 0.80(\mathrm{a})$ & $8.11 \pm 1.94(\mathrm{a})$ & $14.22 \pm 3.61(\mathrm{a})$ & $209 \pm 117$ (b) \\
\hline
\end{tabular}




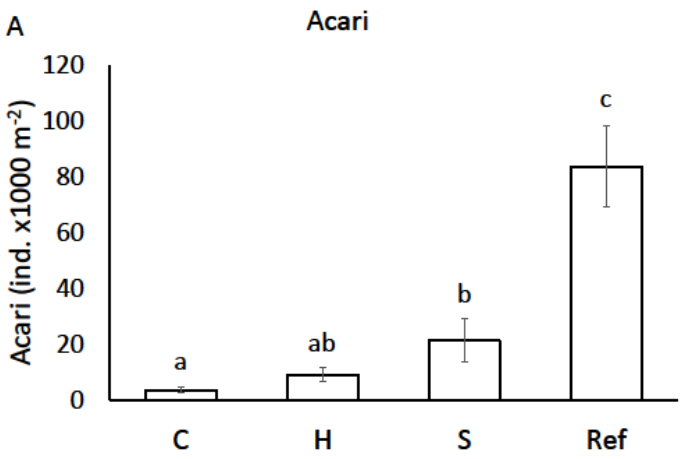

530

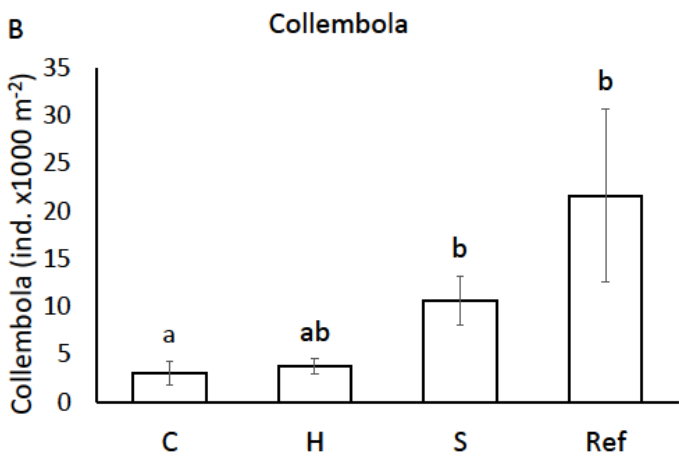

531

532

533

534

535

536

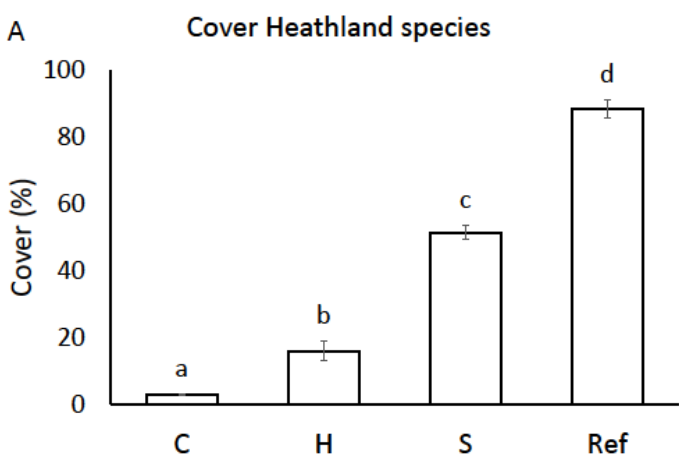

537 


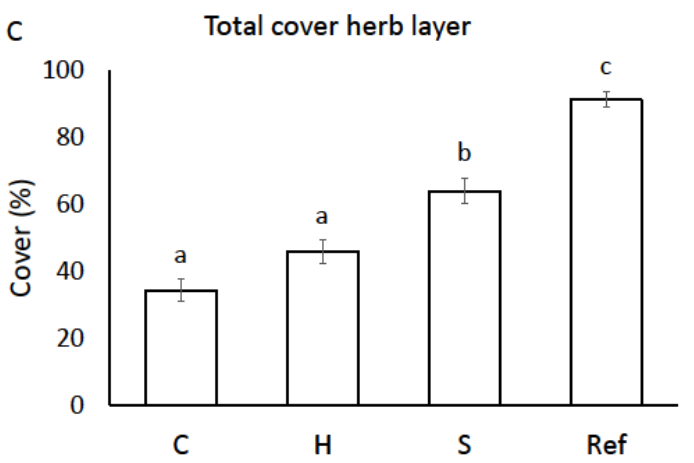

Figure 4. Cover of heathland species (A), mesotrophic grassland species (B) and total herb cover (C) 541 after 3 years. Means \pm SE, letters indicate Tukey outcomes. C: control; H: herbage; S: sods and Ref: 542 reference heathland.

543
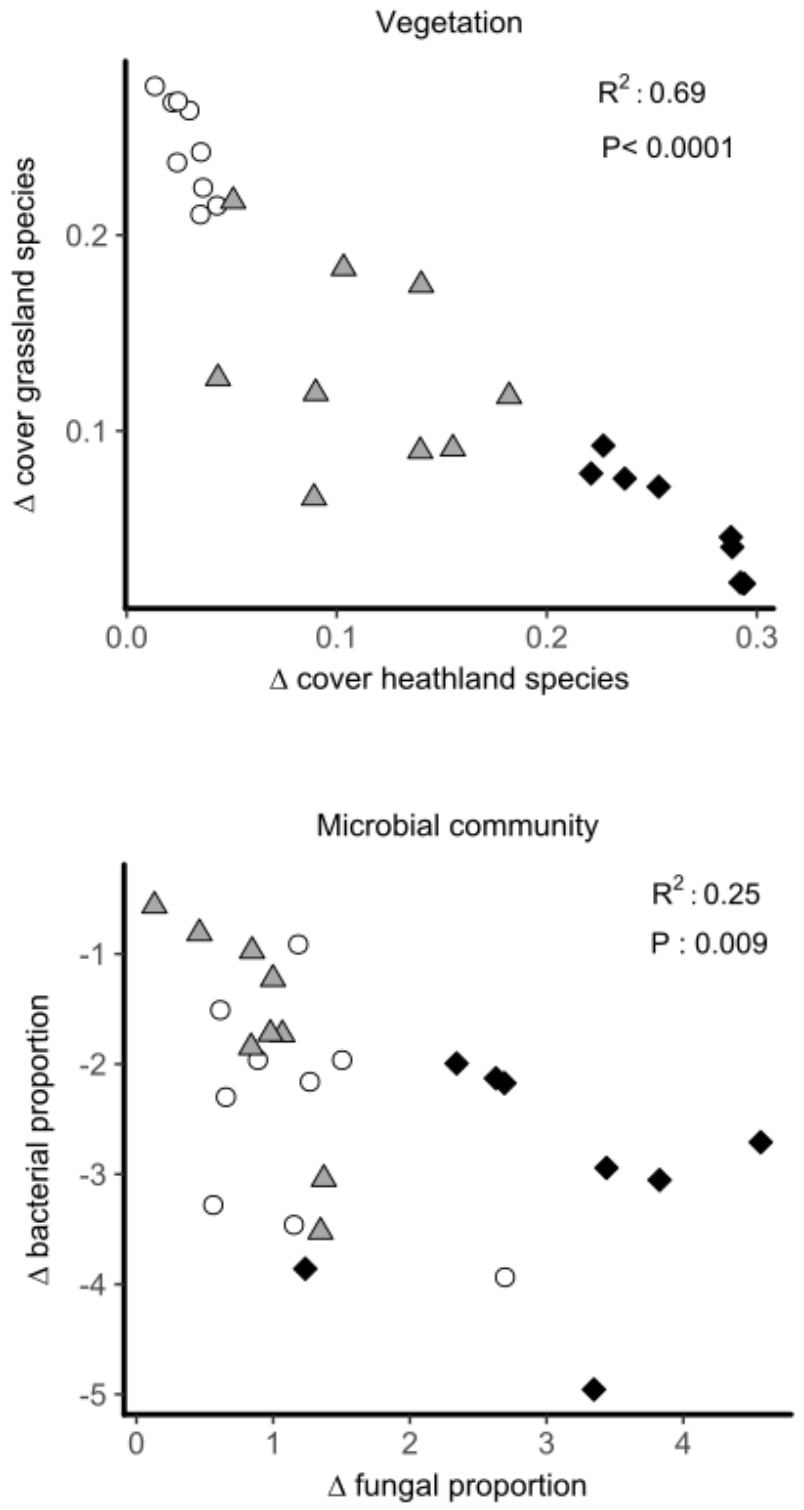


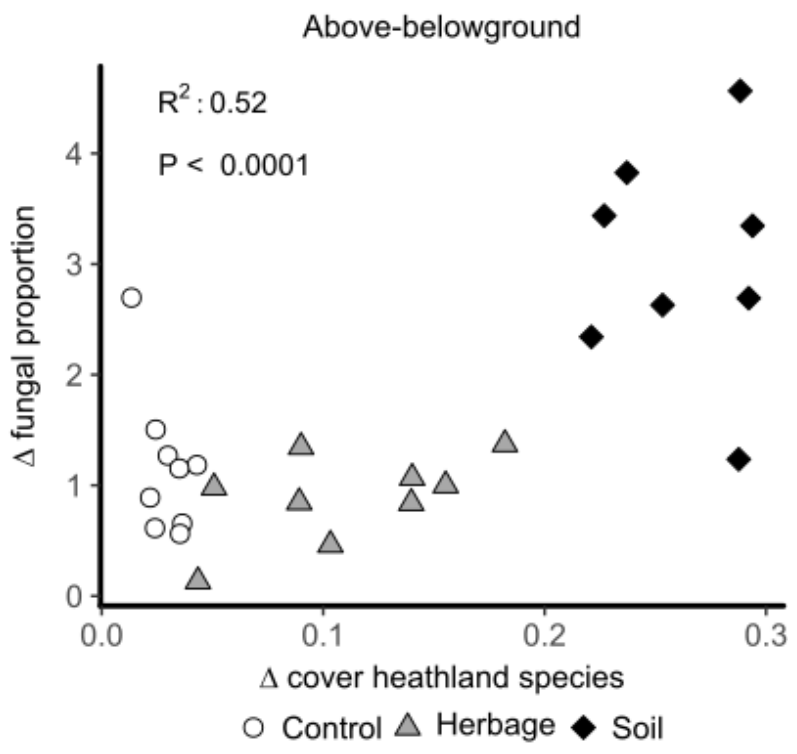

544

545 Figure 5. Correlations in the rate of change per year $(\triangle)$ within the above- $(A)$ and below-ground (B) 546 communities and between above- and belowground target species (C). $\triangle$ cover plant species in 547 fraction of total cover per year, $\triangle$ microbes in mol\% per year. 
Table 1. Linear Mixed model results soil chemistry

IBM SPSS version 21

Mixed Model Analisis

Dry site only

Fixed:

Random:

Sample dates:

treatment ( 9 treatments)
Block
Time

4-4-2012

17-10-2012

9-4-2013

29-10-2013
Treatments (Full factorial, random design, $n=3$ )

$\begin{array}{lll}\text { Acidified } & \text { elemental S } & 1500 \mathrm{~kg} / \mathrm{ha} \\ \text { Limed } & \text { Dolokal } & 2000 \mathrm{~kg} / \mathrm{ha} \\ \text { Control-pH } & \text { No addition } & - \\ \text { Fresh Hay } & & 1: 2 \\ \text { Sods } & & 1: 15 \\ \text { Control-Biota } & \text { No addition } & -\end{array}$

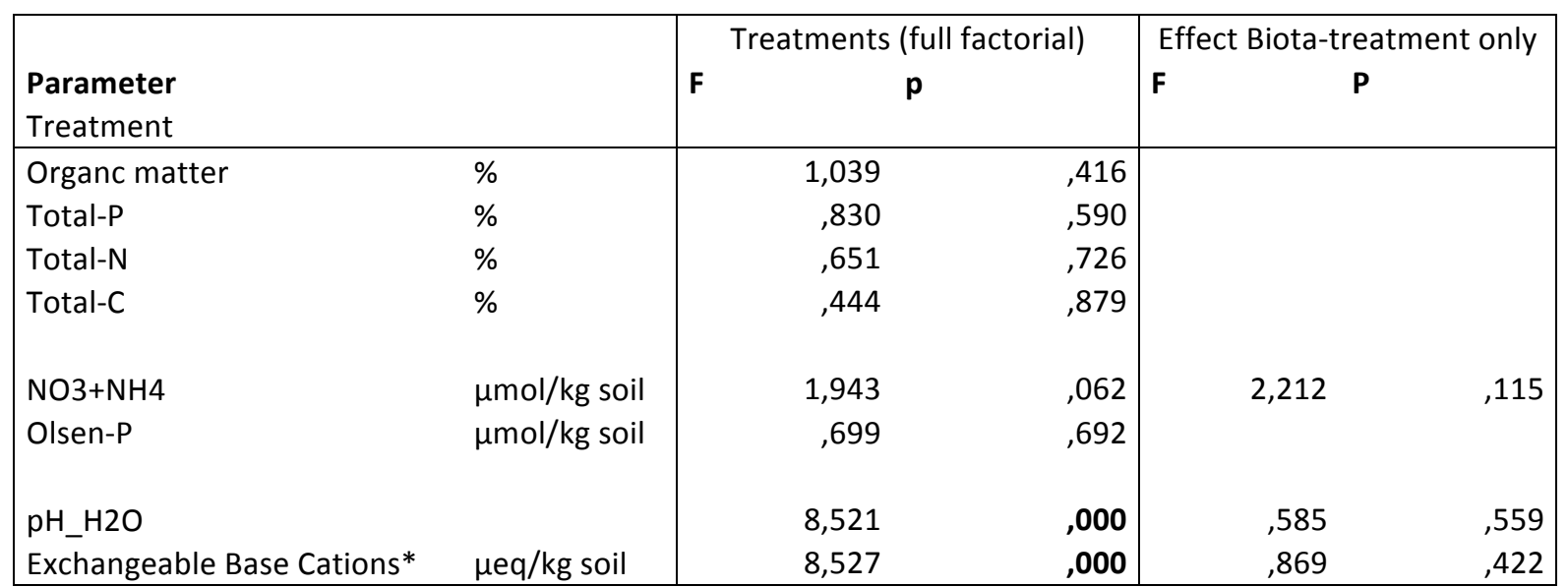




\begin{tabular}{|c|c|c|c|c|c|c|c|c|}
\hline \multirow{2}{*}{\multicolumn{2}{|c|}{$\mathrm{pH}$-treatment }} & \multicolumn{7}{|l|}{ Mean } \\
\hline & & Aci & dified & & Con & l-pH & & $\mathbf{L}$ \\
\hline \multicolumn{2}{|l|}{ Biota-treatment } & Control_Biota & Fresh Hay & Sod & Control_Biota & $\begin{array}{c}\text { Fresh } \\
\text { Hay }\end{array}$ & Sod & Control_Biota \\
\hline Organc matter & $\%$ & 2,02 & 2,09 & 2,58 & 1,84 & 2,26 & 1,75 & 3,47 \\
\hline Total-P & $\%$ & 0,86 & 1,02 & 0,9 & 0,98 & 1,32 & 0,81 & 1,23 \\
\hline Total-N & $\%$ & 0,06 & 0,07 & 0,06 & 0,06 & 0,05 & 0,04 & 0,05 \\
\hline Total-C & $\%$ & 1,25 & 1,58 & 1,24 & 1,31 & 1,06 & 0,98 & 0,97 \\
\hline NO3+NH4 & $\begin{array}{l}\mu \mathrm{mol} / \mathrm{kg} \\
\text { soil } \\
\mu \mathrm{mol} / \mathrm{kg}\end{array}$ & 39,5 & 42,8 & 38,6 & 35,9 & 46,8 & 30,7 & 46,6 \\
\hline Olsen-P & soil & 193 & 236 & 245 & 265 & 296 & 264 & 226 \\
\hline $\begin{array}{l}\text { pH_H2O } \\
\text { Exchangeable Base }\end{array}$ & & 5,5 & 5,67 & 5,52 & 5,91 & 5,8 & 5,82 & 6,22 \\
\hline Cations & $\mu e q / \mathrm{kg}$ soil & 8205 & 10251 & 8555 & 8602 & 11437 & 9278 & 14790 \\
\hline
\end{tabular}


Table 2. Results ANOVA model on inocula gradient with pooled $\mathrm{pH}$ data. In separate analyses either differences along the inoculation gradient within the experiment were tested after which they were compared to the reference heathlands. For the soil community $n=9$ per treatment, for the vegetation $n=18$, for the reference heathlands $n=3 . *$ : $\ln (x+1)$ transformed. C: control; H: hay addition, S: sod inoculation, GR: deep horizon original agricultural grassland (only microbes) and Ref: reference heathlands.

\begin{tabular}{|c|c|c|c|c|c|c|c|c|c|c|c|c|c|c|c|}
\hline \multirow{3}{*}{$\begin{array}{l}\text { Compone } \\
\text { nt }\end{array}$} & \multirow[t]{3}{*}{ Parameter } & \multicolumn{6}{|c|}{ ANOVA model experiment } & & \multicolumn{7}{|c|}{ ANOVA model experiment + reference } \\
\hline & & \multicolumn{3}{|c|}{ Inocula } & \multicolumn{3}{|c|}{$\begin{array}{l}\text { Tukey } \\
\text { test }\end{array}$} & \multicolumn{3}{|c|}{ Inocula } & \multicolumn{5}{|c|}{ Tukey test } \\
\hline & & d.f & $F$ & $P$ & $\mathbf{C}$ & $\mathbf{H}$ & $\mathbf{S}$ & d.f & $\boldsymbol{F}$ & $P$ & $\begin{array}{l}\mathbf{G} \\
\mathbf{R}\end{array}$ & $\mathbf{C}$ & $\mathbf{H}$ & $\mathbf{S}$ & $\begin{array}{l}\operatorname{Re} \\
f\end{array}$ \\
\hline \multirow[t]{2}{*}{ Microbes } & Fungal marker & 2 & $\begin{array}{l}25.1 \\
5\end{array}$ & $\begin{array}{l}<0.000 \\
1\end{array}$ & a & a & $\mathrm{b}$ & 4 & 31.37 & $\begin{array}{l}<0.000 \\
1\end{array}$ & $\mathrm{a}$ & $\mathrm{a}$ & a & $\mathrm{b}$ & c \\
\hline & $\begin{array}{l}\text { Bacterial } \\
\text { markers }\end{array}$ & 2 & 3.90 & 0.0348 & $\mathrm{a}$ & a & $a$ & 4 & 3.54 & 0.0190 & a & $\begin{array}{l}a \\
b\end{array}$ & $\begin{array}{l}a \\
b\end{array}$ & $\mathrm{~b}$ & $a b$ \\
\hline \multirow[t]{5}{*}{$\begin{array}{l}\text { Nematod } \\
\text { es }\end{array}$} & $\begin{array}{l}\text { Bacteriophago } \\
\text { us* }\end{array}$ & 2 & 4.79 & 0.0178 & a & $\begin{array}{l}a \\
b\end{array}$ & $\mathrm{~b}$ & 3 & 32.37 & $\begin{array}{l}<0.000 \\
1\end{array}$ & & $\mathrm{a}$ & $\begin{array}{l}a \\
b\end{array}$ & $\mathrm{~b}$ & c \\
\hline & $\begin{array}{l}\text { Phytophagous } \\
*\end{array}$ & 2 & 4.06 & 0.0304 & $a$ & $\begin{array}{l}a \\
b\end{array}$ & $b$ & 3 & 7.96 & 0.0006 & & $a$ & $a$ & $a$ & $b$ \\
\hline & Mycophagous* & 2 & 2.75 & 0.0841 & $a$ & $a$ & $a$ & 3 & 10.63 & $\begin{array}{l}<0.000 \\
1\end{array}$ & & $a$ & $a$ & a & $b$ \\
\hline & Omnivorous* & 2 & 0.69 & 0.5111 & $\mathrm{a}$ & a & $a$ & 3 & 2.15 & .1185 & & $\mathrm{a}$ & $a$ & $a$ & $a$ \\
\hline & Total* & 2 & 2.84 & 0.0779 & $a$ & $a$ & a & 3 & 15.67 & $\begin{array}{l}<0.000 \\
1\end{array}$ & & $a$ & $a$ & $a$ & $b$ \\
\hline \multirow[t]{3}{*}{$\begin{array}{l}\text { Mesofaun } \\
\text { a }\end{array}$} & Acari* & 2 & 6.63 & 0.0051 & $a$ & $\begin{array}{l}a \\
b\end{array}$ & $b$ & 3 & 13.50 & $\begin{array}{l}<0.000 \\
1\end{array}$ & & $a$ & $\begin{array}{l}a \\
b\end{array}$ & $\mathrm{~b}$ & c \\
\hline & Collembola* & 2 & 3.80 & 0.0369 & $a$ & $\begin{array}{l}a \\
b\end{array}$ & $b$ & 3 & 4.02 & 0.0173 & & $a$ & $\begin{array}{l}a \\
b\end{array}$ & $b$ & $b$ \\
\hline & Total* & 2 & 7.47 & 0.0030 & $a$ & $\begin{array}{l}a \\
b\end{array}$ & $b$ & 3 & 13.38 & $\begin{array}{l}<0.000 \\
1\end{array}$ & & $a$ & $\begin{array}{l}a \\
b\end{array}$ & $b$ & c \\
\hline \multirow[t]{3}{*}{$\begin{array}{l}\text { Vegetatio } \\
\mathrm{n}\end{array}$} & $\begin{array}{l}\text { Cover heatland } \\
\text { species }\end{array}$ & 2 & $\begin{array}{l}81.0 \\
1\end{array}$ & $\begin{array}{l}<0.000 \\
1\end{array}$ & $a$ & $b$ & c & 3 & $\begin{array}{l}120.3 \\
3\end{array}$ & $\begin{array}{l}<0.000 \\
1\end{array}$ & & a & $b$ & c & $d$ \\
\hline & $\begin{array}{l}\text { Cover } \\
\text { grassland } \\
\text { species }\end{array}$ & 2 & $\begin{array}{l}12.4 \\
4\end{array}$ & $\begin{array}{l}<0.000 \\
1\end{array}$ & $a$ & $\mathrm{~b}$ & c & 3 & 13.78 & $\begin{array}{l}<0.000 \\
1\end{array}$ & & $a$ & $b$ & $\begin{array}{l}\mathrm{b} \\
\mathrm{c}\end{array}$ & c \\
\hline & $\begin{array}{l}\text { Total cover } \\
\text { herb layer }\end{array}$ & 2 & $\begin{array}{l}17.8 \\
2 \\
\end{array}$ & $\begin{array}{l}<0.000 \\
1\end{array}$ & $a$ & a & $b$ & 3 & 29.06 & $\begin{array}{l}<0.000 \\
1\end{array}$ & & $a$ & $a$ & $b$ & c \\
\hline
\end{tabular}


Table 3. Correlations between different parameters within and between communities. Paired values of all experimental plots $(n=27)$. Probabilities marked with an asterisk are significant after application of a Bonferroni correction to control the Type

I error rate

\begin{tabular}{|c|c|c|c|c|c|}
\hline Interaction & Level & Parameter 1 & Parameter 2 & Correlation & $P$ \\
\hline \multirow[t]{13}{*}{ Within communities } & Microbes & Fungal marker & $\begin{array}{l}\text { Bacterial } \\
\text { markers }\end{array}$ & -0.635 & $0.0005^{*}$ \\
\hline & \multirow[t]{6}{*}{ Nematodes } & Bacteriophagous & Mycophagous & 0.627 & $0.0005^{*}$ \\
\hline & & Bacteriophagous & Phytophagous & 0.349 & 0.0742 \\
\hline & & Mycophagous & Phytophagous & 0.493 & 0.0090 \\
\hline & & Total nematodes & Bacteriophagous & 0.897 & $<0.0001^{*}$ \\
\hline & & Total nematodes & Phytophagous & 0.463 & 0.0151 \\
\hline & & Total nematodes & Mycophagous & 0.704 & $<0.0001^{*}$ \\
\hline & \multirow[t]{3}{*}{ Mesofauna } & Acari & Collembola & 0.841 & $<0.0001 *$ \\
\hline & & Total mesofauna & Acari & 0.988 & $<0.0001^{*}$ \\
\hline & & Total mesofauna & Collembola & 0.916 & $<0.0001^{*}$ \\
\hline & \multirow[t]{3}{*}{ Vegetation } & Cover heathland & Cover grassland & -0.595 & $0.0011 *$ \\
\hline & & Total cover & Cover heathland & 0.858 & $<0.0001^{*}$ \\
\hline & & Total cover & Cover grassland & -0.199 & 0.3206 \\
\hline \multirow[t]{19}{*}{ Between communities } & \multirow{4}{*}{$\begin{array}{l}\text { Microbes - } \\
\text { vegetation }\end{array}$} & Fungal marker & Cover heathland & 0.753 & $<0.0001^{*}$ \\
\hline & & Fungal marker & Cover grassland & -0.342 & 0.0876 \\
\hline & & $\begin{array}{l}\text { Bacterial } \\
\text { markers }\end{array}$ & Cover heathland & -0.462 & 0.0176 \\
\hline & & $\begin{array}{l}\text { Bacterial } \\
\text { markers }\end{array}$ & Cover grassland & -0.008 & 0.9711 \\
\hline & \multirow{2}{*}{$\begin{array}{l}\text { Microbes - } \\
\text { nematodes }\end{array}$} & Fungal marker & Mycophagous & 0.321 & 0.1101 \\
\hline & & $\begin{array}{l}\text { Bacterial } \\
\text { markers }\end{array}$ & Bacteriophagous & -0.154 & 0.4538 \\
\hline & \multirow{6}{*}{$\begin{array}{l}\text { Microbes - } \\
\text { mesofauna }\end{array}$} & Fungal marker & Acari & 0.589 & $0.0015^{*}$ \\
\hline & & Fungal marker & Collembola & 0.753 & $<0.0001^{*}$ \\
\hline & & Fungal marker & Total mesofauna & 0.656 & 0.0003 \\
\hline & & $\begin{array}{l}\text { Bacterial } \\
\text { markers }\end{array}$ & Acari & -0.320 & 0.1111 \\
\hline & & $\begin{array}{l}\text { Bacterial } \\
\text { markers }\end{array}$ & Collembola & -0.489 & 0.0112 \\
\hline & & $\begin{array}{l}\text { Bacterial } \\
\text { markers }\end{array}$ & Total mesofauna & -0.380 & 0.0557 \\
\hline & \multirow{4}{*}{$\begin{array}{l}\text { Nematodes - } \\
\text { vegetation }\end{array}$} & Phytophagous & Total cover & 0.321 & 0.1027 \\
\hline & & Phytophagous & Cover heathland & 0.336 & 0.0866 \\
\hline & & Phytophagous & Cover grassland & 0.161 & 0.4218 \\
\hline & & Total nematodes & Total cover & 0.329 & 0.0939 \\
\hline & \multirow{3}{*}{$\begin{array}{l}\text { Mesofauna - } \\
\text { vegetation }\end{array}$} & Acari & Cover heathland & 0.342 & 0.0810 \\
\hline & & Collembola & Cover heathland & 0.361 & 0.0642 \\
\hline & & Total mesofauna & Total cover & 0.239 & 0.2299 \\
\hline
\end{tabular}

